\title{
The Crossroads of Critical Social Work Practice in the Context of an Institutionalised System of Social Services in the Czech Republic Radka Janebová
}

\begin{abstract}
:
Critical social work practice is (amongst other things) a response to the expansion of neo-liberal ideology. Under such circumstances, it is not particularly easy for this practice to survive. This paper is devoted to organisations whose practice can be or could have been considered critical in the context of the Czech Republic. The aim will be to reflect the selected organisations implementing critical practice and their functioning in relation to the institutionalised system of social services. We will also follow the consequences that integration into the system may have for their critical practice. Examples of the functioning of selected organisations can show how they deal with a dilemma. This dilemma incudes two ways: either to formalise one's existence (enter an institutionalised social service system, and provide relative financial stability for itself with the risk of the downsizing of critical practice), or remain deformed (to fight financial uncertainty, but have greater freedom to practise critical practice).
\end{abstract}

Keywords: critical practice, social work, social services, institutionalisation, deformation, neoliberalism, financing

\section{Introduction}

The aim of the article will be to reflect on the functioning of selected organisations implementing the critical practice of social work in the Czech Republic in relation to the institutionalised system of social services. We will also reflect on the consequences that integration into the system may have for their critical practice. Social work does not happen in a vacuum. It always reflects the context in which it takes place. Thus, I will try to put my findings in one of the most important contemporary contexts - in the dominant neoliberal discourse. The text is based on a starting point which is critical to this discourse - the critical social work and criticism of neoliberalism by Loïca Wacquant. Before reaching the stated aim, I would like to briefly clarify the role of social work in the neoliberal society, as perceived from a critical position. I would also like to define what I understand by critical practice. Only then can I formulate hypotheses about the functioning of organisations implementing the critical practice in the institutionalised system of social services and the impact of such functioning on their critical practice. Presented outputs should be 
understood only as hypotheses derived inductively from the abovementioned articles and from the study of documents (webpages, Facebook profiles of the mentioned organisations, and articles related to the events described). It is necessary to point out that the formulated hypotheses are influenced by the declared critical position.

\section{The Role of Social Work in Neoliberal Society from a Critical Position}

Social work is logically influenced by the context in which it is based and in which it engages. In countries that are referred to as the rich North in global studies, there has been a series of events since the 1970s that have had a major impact on national economies and on the development of welfare states. Among them were the Vietnam War, the unsustainable gold-backed dollar and the subsequent end of the Bretton Woods system, and the Yom Kippur War between Israel and its Arab neighbours followed by an increase in oil prices. ${ }^{1}$ Subsequent global economic stagnation has raised a number of issues in the area of the welfare states functioning. The crisis of legitimacy of prevailing Keynesian states (seeking to balance the negative effects of market mechanisms on people's lives) has been better used by liberals. They have argued for the unacceptability of continued state interference in the freedom of people, push governments to restrict interventionism, and promote the free market and property rights as key principles of the newly functioning states. ${ }^{2}$ A new dominant ideological paradigm has emerged - neoliberalism, which, by some authors, has been called the neoliberal revolution. ${ }^{3}$

Neoliberalism can be understood economically, that is, as a stream of thoughts in the field of economics only. This view is based on the assumption that the highest level of social well-being of the whole society will be achieved through the principles of individual responsibility, the promotion of free market principles, and the minimalisation of the role of the state. Neoliberalism can also be understood very broadly in the sense of Foucault's concept of governmentality, ${ }^{4}$ that is, it is a practice of governance which combines the specific technologies of power aimed at shaping the mentality of subjects in their daily functioning. Given that the first concept is considerably simplistic and the second does not specify the role of state, market, and citizenship (when controlling people), the French social anthropologist and sociologist Loïc Wacquant defines the third notion of neoliberalism. He calls it the centaur state. ${ }^{5}$ In it, neoliberalism does not seek to dismantle the state. The state is understood as a regulator (not a de-regulator) that shapes citizenship according to market requirements. This model is based on the notion that neoliberalism is not an economic but a political project of partnership between the state and capital. In a similar way, David Harvey, ${ }^{6}$ the author of $A$ Brief History of Neoliberalism, perceives neoliberalism as a political project that aims to keep the power of employees under control (due to a feeling of endangerment within the ruling class). He sees that it also optimises the conditions for capital accumulation and for maintaining the power of economic elites. The means to achieve these goals is the state in the service of capital. According to both authors, this is also the reason why the state still exists. Capital itself is not able to create conditions for its accumulation. It needs the state to survive,

Bob MULLALY, The New Structural Social Work, Ontario: Oxford University Press, 2007.

Ian HYSLOP, Neoliberalism and Social Work Identity, European Journal of Social Work 1/2018, pp. 20-31.

Petr KRČÁL and Jiří MERTL, Reflexe neoliberalismu v sociální teorii a politické filosofii, in: Neoliberalismus a marginalita, studie z českého reálkapitalismu, ed. Lubomír Lupták et al., Brno: Doplněk, 2013, pp. 7-42.

Michel FOUCAULT, Ethics: Subjectivity and Truth, ed. Paul RABINOW, New York: The New Press, 1997.

5 Loïc WACQUANT, Three Steps to a Historical Anthropology of Actually Existing Neoliberalism, Social Anthropology/Anthropologie Sociale 1/2012, pp. 66-79.

6 David HARVEY, A Brief History of Neoliberalism, Oxford: Oxford University Press, 2005. 
work for it, and bring benefits to it. Given the fact that the state is the main sponsor of social work, this concept of neoliberalism from a critical position appears to be the optimal starting point for a discussion about the role of social work in the era of neoliberalism.

Although the Czech Republic did not share the neo-liberal revolution with the countries of the rich North in the 1970s and 80s, it underwent this process in a flash immediately after the Velvet Revolution when the country decided to follow the Washington Consensus. This 10-point manual created by the International Monetary Fund in 1989 is based on a return to classical economics and completely ignores the fact that revenue is the problem of balanced budgets, not the costs. ${ }^{7}$ When the government of Vaclav Klaus, under the slogan 'belt tightening', became inspired by the Washington Consensus and began to apply a policy of cuts (officially referred to as disciplined fiscal policy), abolition of tax progression, selling labour at a low price, disadvantageous trade liberalisation leading to the colonisation of the Czech economy, and expropriation of state enterprises under the aegis of privatisation and deregulation, ${ }^{8}$ they basically carried out a neoliberal turbo-revolution. The cuts (in neoliberal logic) must primarily relate to the reduction of state functions - especially in the social sphere. The right-wing government of Petr Nečas realised the second wave of cuts in 2010-2013. A major consequence of Drábek's reforms was a drastic social downturn for the socially weakest people in society.

Wacquant's ${ }^{9}$ centaur state has two essential tasks. Firstly, it should regulate the environment to ensure corporate profit, and secondly, it should discipline people, especially members of the lower classes. It uses four policies for those purposes. Through economic policy, it seeks to commodify areas that are still uncontrolled by the market, and it wants cut spending in areas that do not yield profit to capital. It transforms social policy from protective to correctional. State aid is not a social right anymore (as it was in Keynesian capitalism). The aid is conditioned by obedience and duty to the state. The purpose of crime policies is to move people who have failed to meet the demands of social policy into the penalty system. ${ }^{10}$ It also helps to restore the state's lost legitimacy in the eyes of 'decent citizens'. Firstly, moral panic is induced (citizens feel threatened by inadaptable people), and secondly, citizens are calmed by strict state intervention against these marginalised people. Cultural politics promotes ideas of individual responsibility as a motivational discourse that mutually connect all the aforementioned policies of the state.

The fundamental impacts of these policies on social work are reflected in the growth of the poor (in the international context, see, for example, Piketty in Keller, ${ }^{11}$ Oxfam, ${ }^{12}$ and in the Czech context, see, for example, Švihlíková, ${ }^{13}$ Tožička, ${ }^{14}$ and Prokop ${ }^{15}$ ), in cost cuts in the area of social work services (these are dedicated to people who, according to the politics, do not deserve financial support - unemployed, inadaptable, homeless people, single mothers; data from the

Ilona ŠVIHLÍKOVÁ, Jak jsme se stali kolonií, Praha: Rybka Publishers, 2015.

Ibid.

WACQUANT, Three..., pp. 66-79.

10 While criminal policy (at the beginning) served primarily to punish and rehabilitate people committing criminal offenses, in the centaur state it is becoming more and more a part of the state's disciplinary 'right hand' which is designed to intervene against the poor.

11 C Jan KELLER, Thomas Piketty: Kapitál ve 21. století (review) (online), Argument, available at: http://casopisargument.cz/2017/01/31/ thomas-piketty-kapital-ve-21-stoleti/, updated 31 January 2017, cited $2^{\text {nd }}$ March 2018.

12 ( ) OXFAM INTERNATIONAL, 5 Shocking Facts about Extreme Global Inequality and How to Even It Up (online), available at: https://www. oxfam.org/en/even-it/5-shocking-facts-about-extreme-global-inequality-and-how-even-it-davos, updated 2018, cited $2^{\text {nd }}$ March 2018.

13 ŠVIHLÍKOVÁ, Jak...

14 @ Tomáš TOŽIČKA, Česká republika je zchudlý stát (online), Deník Referendum, available at: http://denikreferendum.cz/clanek/24313ceska-republika-je-zchudly-stat, updated $19^{\text {th }}$ December 2016, cited $5^{\text {th }}$ March 2018.

15 C Daniel PROKOP, Výzkum chudých (online), Praha: Median, available at: http://data.idnes.cz/soubory/domaci/A161114_NEH_009_ CHUDOBA1_MEDIAN.PDF, updated 27 $7^{\text {th }}$ October 2016, cited $5^{\text {th }}$ March 2018. 
Czech Statistical Office in $2017^{16}$ suggest that in the case of the poor who 'deserve' financial help, the cuts are not such a big problem: the more serious problem is a long-term under-financing of the social protection system), and in the competition between services (that produces servile behaviour towards contracting entities and limits efforts to enforce client rights; see, for example, Hloušková, ${ }^{17}$ Valová and Janebová, ${ }^{18}$ and Janebová et al $\left.{ }^{19}\right)$. So it seems that neoliberalism can fundamentally limit the ability or possible willingness of social work to promote human rights and social justice, fight poverty and injustice, and to promote ethical imperatives of aid. ${ }^{20}$ Conversely, it can lead to exaggerated control, imposition of social standards, pacification, and disciplining of people (see, for example, Leonard, ${ }^{21}$ Day, ${ }^{22}$ Mertl, ${ }^{23}$ Janebová and Truhlářová, ${ }^{24}$ and Janebováa ${ }^{25}$ ). The opinion that social work is entering the service of the neoliberal state and is becoming more and more the disciplining tool of such a state leads some critical authors towards using new titles. They call social workers soft cops (e.g., Day, ${ }^{26} \mathrm{Messing}^{27}$ ). This entitling can be translated as 'nice cops. Critical social work is trying to respond to this situation in which social work resigns from its helping mission and enters the centaur state.

\section{Critical Practice of Social Work in the Czech Republic and Ways of Its Implementation}

Critical social work includes a variety of different approaches (structuralist, radical, feminist, anti-racist, transnational, postmodernist, anti-oppressive, etc.). However, some common features can be found in them. It emphasises the analysis of the power mechanisms leading to inequality and oppression in society, the participation of people in solving their problems, the empowerment of people to do collective actions in order to achieve social change, and the desire of the oppressed and powerless to achieve social change (it wants to stay by the side of those people during such actions)..$^{28}$ The causes of the emergence of social problems are seen in structural aspects, such as the unfair or exploitative social order between social strata, genders, races, sexual identities, age groups, etc. From the point of view of critical social work, people's individual problems are always determined by social organisation. ${ }^{29}$

16 C ČESKÝ STATISTICKÝ ÚŘAD, Vybrané údaje o sociálním zabezpečení za rok 2016 (online), available at: https://www.czso.cz/ documents/10180/46002380/19002917.pdf/30a86875-3361-44c4-ae3c-d3ad502f68fa?version=1.0, updated $10^{\text {th }}$ November 2017, cited $22^{\text {nd }}$ February 2018.

17 Zuzana HLOUŠKOVÁ, Etické aspekty účasti poskytovatelů v procesech komunitního plánování sociálních služeb, in: Etika sociální práce, ed. Miroslav KAPPL, Martin SMUTEK and Zuzana TRUHLÁŘOVÁ, Hradec Králové: Gaudeamus, 2010, pp. $223-228$.

18 Hana VALOVÁ and Radka JANEBOVÁ, 'Antiradikálnost' českých sociálních služeb aneb jak organizace sociálních služeb řeší pokles finančních prostředků, Sociální práce / Sociálna práca 1/2015, pp. 5-23.

19 Radka JANEBOVÁ, Marcela HUDEČKOVÁ, Romana ZAPADLOVÁ and Jana MUSILOVÁ, Př́běhy sociálních pracovnic a pracovníků, kteří nemlčeli - Popis prožívaných dilemat, Sociální práce / Sociálna práca 4/2013, pp. 66-83.

20 Carolyn NOBLE, Postmodern Thinking Where is It Taking Social Work?, Journal of Social Work 3/2004, pp. $289-304$.

21 Peter LEONARD, The Function of Social Work in Society, in: Talking about Welfare: Readings in Philosophy and Social Policy, ed. Noel W. TIMMS and David WATSON, Boston: Routledge and Kegan Paul, 1976, pp. 252-266.

22 Phyllis J. DAY, Social Welfare: Context for Social Control, The Journal of Sociology \& Social Welfare 1/1981, pp. 29-44.

23 Jiři MERTL, Přerozdělování welfare. Nátroj pomoci, nebo kontroly?, Brno: Doplněk, 2017.

24 Radka JANEBOVÁ and Zuzana TRUHLÁŘOVÁ, Téma kontroly ve vybraných etických kodexech sociální práce, Caritas et veritas 2/2018, pp. 196-209, further cf. Radka JANEBOVÁ, Vybrané principy kritické sociální práce v kontextu kontroly nedobrovolných klientů, Sociální práce / Sociálna práca 3/2018, pp. 5-21.

25 Radka JANEBOVÁ, Posedlost sociální práce managementem rizik a rezignace na potřeby, Sociální práce/ Sociálna práca, 6/2018, pp. 39-56.

26 DAY, Social...

27 Jill T. MESSING, The Social Control of Family Violence, Affilia 2/2011, pp. 154-168.

28 Karen HEALY, Reinventing Critical Social Work: Challenges from Practice, Context and Postmodernism, Critical Social Work 1/2001.

29

Jan FOOK, Radical Casework: A Theory of Practice, Sydney, Australia, Allen \& Unwin, 1993. 
Given the fact that critical social work has not been significantly established yet in the Czech social work and I have not been able to find practically active organisations of social work which would clearly identify with this stream, I use the term 'critical practice'. Rather, it focuses on fulfilling the characteristics of critical practice rather than identifying with a set of ideas that characterise critical social work.

When Barbora Celá ${ }^{30}$ and I were looking for the abovementioned features of critical social work in Czech practice, we found several organisations and associations whose activities could be labelled as critical practice (e.g., Konexe, Jako doma, Vzájemné soužití, Český západ, ASLIDO, and KRISA). However, our research also showed that the activities were not declared as critical social work by most of those organisations. They took place either intuitively without a reflection of their relationship to social work in general terms or to critical social work, or they based their identity on opposing mainstream social work, and they declared themselves to be part of activism. Critical practice activities were mainly promoted through the KRISA platform (Critical Social Action) which openly declares itself to be a part of critical social work on Facebook: 'We are social workers who want to do social work differently! We spread critical social work - in theory and practice.'

Following previous research, ${ }^{31} \mathrm{I}$ tried to distinguish four ways of implementing critical principles of social work in the Czech Republic. These resulted from the application of two criteria (see Table 1). The first criterion assesses to what extent activities with the features of critical social work are recognised by its implementers as critical social work. The second criterion monitors whether the activities are performed within the system or outside the system of social services. This criterion comes from Bob Mullaly ${ }^{32}$ and his 'new structural social work'. He has distinguished two ways of achieving change in society. The first, more moderate way 'working within (and against) the system' aims to provide support and assistance to people disadvantaged by the existing welfare institutions of the social state and their reform. It is associated with intrapsychic and interpersonal work based on the principles of raising people's awareness, empowerment, and radicalisation of existing social work organisations. The second, more radical way 'working outside (and against) the system' considers the existing social system unreformable because inequality and oppression is an integral part of it. Therefore, it focuses on activities that may lead to a change in the social order, or on activities that operate independently of the state social protection system (for example, establishment of alternative services and organisations, interest coalitions, networks and social movements, cooperation with progressive trade unions, efforts to radicalise professional associations, involvement in politics in a form of progressive political entities). The boundary between 'inside' and 'out' is to be understood as imaginary or blurred since sometimes both strategies can be distinguished only with great difficulty. At the same time, it should be emphasised that the aim of this paper is not to assess the adequacy or inadequacy of these methods but merely to suggest a link between their 'radicality' and institutionalisation.

30 Radka JANEBOVÁ and Barbora CELÁ, Kritická praxe mezi 'jinou’ sociální prací a aktivismem, Sociální práce / Sociálna práca 2/2016, pp. 22-38.

31 Radka JANEBOVÁ, Reflexe kritické praxe sociální práce v ČR, in: Proměny a př́ležitosti sociální práce $v$ ČR, Sborník $z$ konference pořádané ke Světovému dni sociální práce, Praha: MPSV, 2017, pp. 55-59.

32 MULLALY, The New..., pp. 287-363. 
Table 1: Four ways of implementing critical principles of social work in the Czech Republic ${ }^{33}$

\begin{tabular}{|l|l|l|}
\hline Criteria & $\begin{array}{l}\text { Reflected critical practice } \\
\text { of social work }\end{array}$ & $\begin{array}{l}\text { Critical practice of social } \\
\text { work without a reflection }\end{array}$ \\
\hline Outside the system & $\begin{array}{l}\text { Organisation: KRISA, AS- } \\
\text { LIDO } \\
\text { Financing: independent of } \\
\text { the state } \\
\text { Methods: system change } \\
\text { (demonstrations, happe- } \\
\text { nings, blockades, networ- } \\
\text { king, open letters, empowe- } \\
\text { ring of people, dealing with } \\
\text { politicians ...) }\end{array}$ & $\begin{array}{l}\text { Organisation: Jako doma, } \\
\text { Konexe } \\
\text { Financing: independent of } \\
\text { the state } \\
\text { Methods: system change } \\
\text { (demonstrations, happe- } \\
\text { nings, blockades, networ- } \\
\text { king, open letters ...) }\end{array}$ \\
\hline Within the system & $\begin{array}{l}\text { I do not know an organi- } \\
\text { sation that would declare } \\
\text { itself this way }\end{array}$ & $\begin{array}{l}\text { Organisation: Český západ, } \\
\text { Vzájemné soužití } \\
\text { Financing: independent or } \\
\text { dependent on the state } \\
\text { Methods: reform of people } \\
\text { and of existing institutions } \\
\text { (raising people's awareness, } \\
\text { participation in reforms, } \\
\text { dealing with politicians ...) }\end{array}$ \\
& \multicolumn{2}{|l}{} \\
\end{tabular}

Organisations that implement social work rather without reflection and outside the system are Jako doma (it is focused on empowering homeless women) or Konexe (aimed at activating Roma communities). Both are organisations that are funded by foundations, funds, and projects, independently of the state. When enforcing people's rights, they use methods such as demonstrations, happenings, open letters, street blocking, pride enhancement, critical action research, dealing with politicians, etc., that is, the common methods of critical social work. However, these organisations do not recognise themselves as critical social work performers. Rather, they consider themselves to be the activist organisations (cf. Janeb, Celá ${ }^{34}$ ). They perceive social work only in a single discourse, in the dominant traditional/conventional/mainstream one which is under the control of neoliberal ideology.

The organisations that promote the principles of critical social work without reflection and within the system are Český západ and Vzájemné soužití (both focus primarily on social work with socially excluded). They belong to the other category (critical practice of social work without reflection) due to the lack of knowledge of critical social work. Most of their funding comes from social services. They use fewer radical methods of critical social work - especially community work methods. They build on the principles of participation and empowerment of people, but they also engage in negotiations with politicians (cf. Janebová and Celá ${ }^{35}$ ). They avoid radical actions. However, the experience of Vzájemné soužití in 2012 (described below) shows that in the Czech Republic verbal criticism of the city administration is considered a radical step that may be followed by sanctions.

33 JANEBOVÁ, Reflexe..., p. 57.

34 JANEBOVÁ and CELÁ, Kritická...

35 Ibid. 
KRISA and ASLIDO (Action Group with Homeless People) are groups that consider themselves (reflectively) as a part of critical social work. They were created and have been functioning rather outside the system. Both are founded on a voluntary basis. While KRISA works only as a platform on Facebook, ASLIDO receives minor financial support from foreign foundations (both are therefore independent of the 'state'). Examples of social work methods can include: the creation of information material for homeless people (Mapa bez domova, a database of services for homeless people; by KRISA); a call for homeless people to report violence at the Prague Main Railway Station (KRISA); a happening in front of the Chamber of Deputies (it was a protest against the prosecution of Miloš Neubauer who created a 'live template' of a dead homeless man on the pavement in protest against the amendment to the Act on Assistance in Material Need); or collective actions of homeless people who wanted to discuss with the representatives of the Ostrava City Council an empty town house in the centre of Ostrava (this house was intended for demolition although it could serve for social housing), with a subsequent open letter to the same City Hall in Ostrava where the deputies were encouraged to act.

The description of four ways of implementing the critical practice of selected organisations in the Czech Republic has not yet proven their connection with institutionalisation and its impact on their critical activities.

\section{Functioning of critical practice in relation to the institutionalised system of social services}

Below I will try to describe the functioning of these organisations in relation to the institutionalised system. I will also present the consequences that inclusion in the system may have for their critical practice and its realisation. In the Czech context, the concrete system is the system of social services. A hypothesis can be deducted from Table 1: organisations that perform critical practice 'within the system' use less critical methods (raising people's awareness, participating in reforms, negotiating with politicians) than organisations 'outside the system' (demonstrations, happenings, blockades, networking, open letters, etc.). Engaging in the system which enforces institutionalisation can limit the ability of organisations to implement some (more radical) critical methods in situations where the use of such methods could be in the interests of clients. ${ }^{36}$

Institutionalisation can be understood as a process of developing or transforming rules and procedures that affect a particular set of human interactions. Its intention is to regulate the social behaviour of people within organisations or the whole of society. ${ }^{37}$ This regulation is achieved by transforming informal rules into structured and formalised systems ${ }^{38}$ that become binding for their members and therefore sanctionable. ${ }^{39}$ In order to be able to carry out their activities within the social services system, critical practice organisations have to undergo an institutionalisation process and to meet the system requirements. The above table information shows that Vzájemné soužití and Český západ joined the social services system.

All of the abovementioned organisations were originally created with the intention to actively promote the rights of the people who were perceived as oppressed or marginalised - that is,

36 These situations are beyond the objective of this paper.

37 (C) Hans KEMAN, Institutionalization (online), available at: https://www.britannica.com/topic/institutionalization, updated 2018, cited $10^{\text {th }}$ October 2018

38 () Merriam-Webster, Institutionalise (online), available at: https://www.merriam-webster.com/dictionary/institutionalise, updated 2018, cited $10^{\text {th }}$ October 2018.

39 Bohumil GEIST, Sociologický slovník, Praha: Viktoria Publishing, 1992, p. 134. 
those who were considered 'neoliberal offenders' by the centaur state. ${ }^{40}$ These include people who have failed to be 'good citizens participating in the market ${ }^{341}$ and did not follow the neoliberal imperative, that is, people who do not have a job and ask the state for social help. ${ }^{42}$ While conventional social work is aimed at correcting the behaviour of neoliberal offenders, that is, reforming their morals (to transform them into Foucault's ${ }^{43}$ homo oeconomicus - that is, entrepreneurs, or Keller's ${ }^{44}$ capitalists with their social capital), a sign of critical practice is that it sees these people as victims of an unjust and oppressive system. In the critical practice view, this oppressive system (with a soft cunning) shifts responsibility for its own failure to the individual.

\section{Institutionalisation and Its Way}

The beginnings of the functioning of critical organisations were largely based on a voluntary basis. The organisations were either entirely without financial resources or with relatively low funding from donations and grants. Those were provided by various foundations. Some of them began to apply for subsidies granted by the state or by local governments due to their own gradual growth (in the number of people they helped, and in the growth of employed co-workers). The moment when organisations decided whether or not to use the subsidies could be described as a crossroads that probably later determined the way of their critical practice.

Some of them decided to apply for subsidies. These were, however, determined by a number of formalised rules. So, they had to go through the process of institutionalisation in order to meet the demands of the contracting authorities. Activities originally performed on the basis of clients' needs were subject to a number of conditions and rules stated in subsidy calls (personnel, procedural, and operational conditions). The key moment was especially the year 2006 when the Social Services Act No. 108/2006 Coll. came into force (with effect from 1 January 2007) and Standards of Quality of Social Services were established. The original relative independence and freedom while implementing critical practice has been largely limited by the rules of subsidy calls and by contracting authorities (who were checking the compliance). In the case of Český západ and Vzájemné soužití, the individual work with clients began to dominate over community work. This change was based on the Social Services Act requirements.

Especially in the case of Český západ, annual reports show the shift of priorities, that is, the performance of social services was prioritised. At the beginning of this church organisation, individual social work did not appear in the mission of the organisation. There were mostly community activities aimed at increasing the participation of the Roma community in public affairs. After enrolment into the local social services network, the performance of social services is put in the first place in their annual reports. Given the legal definition of social services (see, for example, $\mathbb{\$}$ $2^{45}$ ), the causes of social problems are perceived as individual. They are based primarily on individual work with clients, on the client's adaptation to the social environment. They do not include activities aimed at changing social structures. The basic activities within the social services (in

40 MERTL, Přerozdělování...

41 Mike DEE, Welfare Surveillance, Income Management and New Paternalism in Australia, Surveillance \& Society 3/2013, pp. 272-286 (translated from the Czech version).

42 MERTL, Přerozdělování...

43 Michel FOUCAULT, Security, Territory, Population. Lectures the Collège de France 1977-1978 (ed. Michel SENELLART), New York: Palgrave MacMillan, 2009.

44 Jan KELLER, Nejistota a di̊věra aneb K čemu je modernitě dobrá tradice, Praha: SLON, 2009.

45 'The assistance must be based on the individual needs of the person, it must help people actively, encourage the development of their autonomy, motivate them to do activities that do not lead to long-term stagnation or deepening of the unfavourable social situation, and it must strengthen their social inclusion.' 
$\$ 35$ in section $\mathrm{j}$ ) are 'assistance with obtaining rights, legitimate interests, and assistance in the procurement of personal matters'. This activity, however, is meant in relation to the nearest social environment. This could be a family or an organisation to which the concrete excluded person is or should be connected. This is reflected, for example, in information systems that record performance where negotiations with politicians, writing open letters, media coverage of the situation, community empowerment, etc. are difficult to record.

Community activities have not disappeared from the activities of Český západ but they appear to be increasingly separated from the majority of society during the years. My hypothesis is also based on my personal experience with one of the employees of this organisation at the MPSV (Ministry of Labour and Social Affairs) conference on the World Social Work Day in 2017. At that time, in response to my contribution about the four ways of implementing critical practice, he was happy to announce that the concept of this organisation had undergone significant changes over the last six months (as it focused on the Standards of Quality of Social Services, and had departed from the original concept of community work). It seems that community-based activities with the attributes of critical practice still survive in the organisation, but they take place in a non-conflicting spirit and primarily at local level. Thus, the process of institutionalisation triggered by the pursuit of stable funding has probably led to a regrouping of the organisation's priorities from community work (aimed at the needs of the excluded) to individualised work. Opatrny' ${ }^{46}$ calls this trend a 'tying' of the charitable task of churches. They pragmatically focus on favoured (paid) social services instead of helping those who are not helped by any of the others. Similarly, Vzájemné soužití has chosen the same path of institutionalisation, although its activities are more ambivalent. Their critical community practice survives mainly in the activities of the director and social worker Sri Kumar Viswanathan. Of course, there are classic individualist-oriented social services funded by subsidies as well. So, the organisation became institutionalised, but at the same time it did not give up its activities which help to enforce clients' rights. This shows the Prednádraží case, which had negative financial implications for the organisation. When in 2012, the Civil Office of the Central Ostrava District of Moravská Ostrava and Přívoz ordered about two hundred inhabitants to vacate their homes within twenty-four hours due to a dysfunctional public sewerage system and a broken-down state of the houses, the organisation stood by a part of the tenants who refused to accept the ultimatum. Vishwanathan also began to criticise the city. He said that they were selling off the municipal property instead of dealing with social housing for the poor. The city district's response came quickly and ordered the Office's legal service to investigate whether Vishwanathan's actions,

which included spreading of false information about the situation in Přednádraží and causing the residents of the street Přednádraží not to comply with the building authority's regulation (according to which they were obliged to evacuate it), could fulfil the factual elements of the criminal act of defamation and the factual elements of instructions to the criminal act of obstructing the execution of an official decision. ${ }^{47}$

46 Michal OPATRNÝ, Charity a diakonie - poskytovatelé sociálních služeb nebo sekundární církevní struktura?, Caritas et veritas 1/2017, pp. 92-97.

47 (C) Úřad městského obvodu Moravská Ostrava a Př́voz, Právníci prošetř́ jednání a výroky pana Kumara (online), available at: http://www. moap.cz/ cs/o-moapu/aktualne/pravnici-prosetri-jednani-a-vyroky-pana-kumara-vishwanathana, last update 2012, cited $10^{\text {th }}$ July 2013. 
The second retaliatory step could be the subsequent expulsion of the organisation from two nonresidential premises where the head office and the social and legal counsel were located for many years (for more details, see Janebová et al. ${ }^{48}$ ).

In addition, other activities aimed at changing mesosystems and macrosystems can be found in the annual reports of Vzájemné soužití. For example, there are negotiations with the Ministry of Culture and the Minister for Human Rights on closing AGPI in Lety, near Písek in South Bohemia, or initiating an urgent meeting of key stakeholders to help people who were dealing with the threat of not receiving additional payment for housing (as a result of the rejection of municipalities). At that time (2015), the solution was found and expressed by the Minister of the Interior in his opinion that the Binding Standpoint of Municipalities 'is not binding' and the Labour Office then paid for the additional payment for housing. In this way, it was managed to temporarily save 18 thousand people from evictions from hostels. The organisation, together with Platforma pro sociální bydlení (the Platform for Social Housing) and Svaz měst a obcí ČR (the Union of Towns and Municipalities of the Czech Republic), participated in the preparation of the act on social housing. Another success of the organisation was that it managed to motivate the city district of Slezská Ostrava to a common quality of education for all children, regardless of their origin and ethnicity. Institutionalisation, therefore, did not prevent Vzájemné soužití from the performance of critical practice, but the organisation itself experienced sanctions for 'disobedience'. It is questionable whether the radicality of its methods is limited now by the fear of repeating the situation in 2012. At present, Vzájemné soužití is engaged in action against the demolition of Bedřiška colony but no radical methods have been used so far.

Incidentally, Člověk v tísni and Poradna pro občanství / Občanská a lidská práva in Ústí nad Labem found themselves in a similar situation of financial threat. This situation was caused by an open letter which was sent to the Municipiality of Ustí nad Labem. They asked the Municipiality to 'respond responsibly to the crisis situation of people who are currently living in closing hostels in Klišská and Purkyňova streets. Their situation is hopeless and the city's responsible intervention is necessary.49 This happened as part of the eviction of two social hostels in Ustí nad Labem in June 2018. After the amendment to the Act on Assistance in Material Need No. 111/2006 Coll., with effect from June 2017, the Municipality of Ustí nad Labem declared in its territory 22 areas with an increased incidence of socially undesirable phenomena. The additional payment for housing (until that time sponsored by the Municipiality) was taken away from the residents of those areas, and 230 people had to leave two closed hostels (mainly families with children, seniors, and disabled). The city of Ustí nad Labem distanced itself from the situation that it had caused. They declared that the city was not obliged to provide alternative apartments. According to them, there is only the obligation of social work or social counselling. Therefore, the city asked the social service provider to carry out screening and start social work aimed at helping people at risk of losing their housing. It was a situation where the state and the city caused the loss of people's homes, but they relieved themselves of their responsibility for dealing with the situation and transferred it to social workers (non-profit organisations and local governments). Social workers then had to deal with a problem using a completely inadequate tool, i.e., counselling.

48 Radka JANEBOVÁ, Marcela HUDEČKOVÁ, Romana ZAPADLOVÁ and Jana MUSILOVÁ, Př́iběhy sociálních pracovnic a pracovníků, kteří nemlčeli - Způsoby řešení dilemat, Sociální práce / Sociálna práca 2/2015, pp. 23-37.

49 Martin KOVALČİ́K, Ústecký magistrát musí lidem z uzavíraných ubytoven pomoci (online), Člověk v tísni, available at: https://www. clovekvtisni.cz/co-delame/socialni-prace-v-cr/ustecky-kraj/ustecky-magistrat-musi-lidem-z-uzaviranych-ubytoven-pomoci-5095gp, last update $6^{\text {th }}$ June 2018, cited $2^{\text {nd }}$ August 2018. 
This neoliberal strategy is often referred to as depoliticisation of governance in foreign literature. ${ }^{50}$ Its aim is to delegate originally political issues to non-political executive bodies, ideally to the non-profit sector. It is a delegation of responsibility. It is a transfer of originally state domains to civil society organisations. The blame for social problems can then be attributed not only to the poor but also to the entrusted entities that do not have adequate tools to address them. In the event of their failure, responsibility would not be attributed to national or regional politicians, but to social workers. For example, Deputy Mayor of Ústí nad Labem, Jiří Madar, responded to the open letter from both organisations in the following way:

The results should speak for themselves. For years, non-profit subjects have been using the financial subsidies of the city, and there is still the same number of inadaptable residents and recipients of social benefits. The number is not decreasing. There is no information about how many of those people were helped (and in what way) by the non-profit organisations (i.e., whether the non-profit organisation helped them to find an official job or change their way of life). Housing in a hostel for a number of them (despite the non-profit organisations' supervision) stopped being a temporary situation and became a permanent norm, and problems only grow. This reality will need to be addressed during the process of grant evaluation (and their further allocation). ${ }^{51}$

It turns out that institutionalisation, which should be the way of better financial security for an organisation, may also have its drawbacks. Specifically, it is the growth of dependence on donors which may complicate the acquisition of the subsidies in the event of 'disobedience'.

\section{The Way Outside Institutionalisation}

At the imaginary crossroads, the second group of organisations decided for a thornier path of existence and did not subordinate to the process of institutionalisation. Given our research and documents on the internet or Facebook pages, this decision appears to be deliberate. It is justified by the desire to maintain independence from the contracting authorities and by the fear that the use of subsidies would limit the variety of more radical methods (and those organisations do not want to give up such methods). KRISA is a platform that (through Facebook) summons people up for a variety of radical actions. As such, it has probably the greatest freedom to use radical methods of critical social work. It is not financially dependent on anyone. The reporting and cancelling of a Facebook profile is its only risk. ASLIDO carried out its activities through smaller projects (mainly Czech-Norwegian grant, Austrian foundation), using volunteers or people who needed supplemental income. In the 2016 annual report, they said they had deliberately decided not to ask for funding for other projects. The freedom to use more radical methods of work may be given to them by the fact that the members of the association are not financially dependent on it.

However, the lower level of institutionalisation associated with the participation of socially excluded people involves several possible risks (for example, the organisation can be overlooked by other entities, there is a lack of cooperation with others, or it can be labelled as a radical entity especially by the municipality). In the case of ASLIDO, for example, this happened in 2016 when not only the Ostrava Municipality (specifically the Social Inclusion Coordinator of Ostrava) but

50 Matthew WOOD and Matthew FLINDERS, Rethinking Depoliticisation: Beyond the Governmental, Policy \& Politics 2/2014, pp. 151-170.

51 ○ ROMEA.CZ, Kauza uzavřených ubytoven v Ústí končí. Lidé opustili tělocvičnu, magistrát útočí na neziskovky a chudé (online), available at: http://www.romea.cz/cz/zpravodajstvi/domaci/kauza-uzavrenych-ubytoven-v-usti-konci-lide-opustili-telocvicnu-magistrat-utoci-naneziskovky-a-chude, last update $24^{\text {th }}$ July 2018, cited $2^{\text {nd }}$ August 2018. 
also Agentura pro sociální začleñování (the Ostrava Branch of the Agency for Social Inclusion) refused to discuss the form of social housing in the Ostrava region with them. Although the representatives of both organisations initially promised their participation, they later distanced themselves from the discussion. They had been given a leaflet calling on people who were in housing need to participate in the discussion, and this was then interpreted as 'radical demands of one of the parties. The leaflet also included Prohlášení o sociálním bydlení, i.e., a Declaration on Social Housing (a statement that was created by a joint effort of groups bringing together people in housing need - Chceme bydlet from Prague, Hnutí pro nové bydlení from Brno and Kruh naděje from Ostrava). This was also marked as radical by both organisations. Among these 'radical demands' were, for example, affordable housing in apartments that are hygienically and technically sound, with basic equipment such as functional heating. The declaration also required the availability of apartments without the requirement of paying a deposit or apartments with supportive social work. This social work should have protected the interests of the tenants. ${ }^{52}$

The fact that less formalised organisations do not have to be taken seriously by the local government is shown in the case of Konexe in 2018 in the abovementioned affair of evicting two hostels in Ustí nad Labem. Although Konexe is an association registered on 1 January 2014 at the Regional Court in Ustí nad Labem, it operates on an informal basis and their members are themselves Roma. This organisation has basically the same experience with the local government representatives as ASLIDO, as the evicted people were not invited to the meeting dealing with their future. Conexe commented this fact on Facebook using the following words: 'We learned that today's meeting was hastily moved to another place as its organisers had learned that we knew about the place. Perhaps they are afraid that people might come whose future should be decided there.'

The advantage of a thornier journey is the financial independence of these organisations applying critical practice. Such a situation enables them to promote human rights via more radical actions. Due to their informal functioning, local governments cannot apply any financial leverage. But that does not mean that members of these associations cannot experience retaliatory actions. In their case, however, these are personal accusations rather than financial punishments. In the case of Konexe, the favourite object of verbal attacks was Miroslav Brož, who publicly spoke about the case of evicted hostels. He publicly asked the city to deal with the availability of decent housing for Roma people and he criticised the announcement of free-from-subsidies zones for which the residents would lose housing subsidies. He considered ethnic segregation as the main cause of housing problems in Ústí. He also wanted people affected by eviction to be a part in the negotiations, and he asked city to ensure this. He refused the decision to relocate evicted persons to the outskirts of Ostrava where they were offered accommodation without water and electricity, but with bedbugs. He was later called an activist by the city's leaders, that is, as a person who discourages residents from working with the city's social workers and non-profit organisations. Deputy Madar said: 'The activist Brož makes it harder for municipal employees to work on the case of evicted hostels. He urges the residents not to seek housing and he attacks the city. We are considering filing a complaint. He is not at all concerned with order in the city, or the peace of the citizens. He just wants to make himself more visible.53

52 @ Eliška ČERNÁ, Přiliš radikální? (online), A2larm, available at: http://a2larm.cz/2016/09/prilis-radikalni/, last update 29 $9^{\text {th }}$ September 2016, cited $10^{\text {th }}$ October 2018.

53 C Zuzana MENDLOVÁ, Ústecký magistrát selhal v integraci Romů, prohlašuje místní aktivista (online), iDNES, available at: https://usti. idnes.cz/aktivista-miroslav-broz-predlice-romove-usti-nad-labem-ubytovny-phl-/usti-zpravy.aspx?c=A180622_124246_usti-zpravy_ vac2, last update $24^{\text {th }}$ June 2018, cited $10^{\text {th }}$ October 2018. 
Organisations that voluntarily resist institutionalisation therefore have greater space for more critical action due to financial independence, but their members are not protected from personal threats or complaints. It can also be assumed that critical involvement in a non-institutionalised organisation can have consequences in other aspects of personal life. Even activist social workers must somehow make a living. If he works in the field of social services or public administration, there is a real risk of retaliation. The target could be the organisation in which they are employed, or even their personal life. If unpaid critical work is being carried out in parallel with paid employment, it is a very exhausting, unsustainable situation in the long-term and it interferes with family life. Thus, there is a risk that these activities will eventually erode due to the fatigue of ideological leaders.

The centaur state seems to have well-thought-out strategies to pacify critical practice. The institutionalised subjects fear losing money for their organisation while the non-institutionalised ones have to solve the need of existential security. In the second case, it is enough to leave them in such situation, or to threaten them from time to time. As a result, they stop making problems as well.

\section{Conclusion and Discussion on How to Implement Critical Practice within the Centaur State}

In this paper, I have presented a hypothesis which says that critical practice organisations have faced or are still facing an existential dilemma. They can either formalise their existence, entering the institutionalised system of social services, and secure relative financial stability with the risk of pressures on their critical practice (that is, they might have to dampen their critical practice), or remain deformed. This deformed state brings financial uncertainty, but (at the same time) provides greater freedom. Such organisations can do critical practice in the interests of clients. Other variables may enter this dilemma.

The continuing critical practice of Kumar Vishwanathan may indicate that even institutionalised social work may not resign from activism. One of the reasons could be the personality of this social worker, who has been involved in governmental and international human rights institutions, has received a range of awards for his work, and has been in contact with major national politicians. Hence, his social capital can reduce concerns about possible sanctions.

Deputy Madar's actions and his threatening can also be ineffective, given the size and political strength of the threatened organisation Člověk v tísni. Merging the organisations into larger social conglomerates (that will have greater strength and independence in local areas and will also have space for political lobbying at national level) might be the way to emancipation. However, in the context of the Ústí nad Labem Region, it will be interesting to follow the fate of Poradna pro občanství / Občanská a lidská práva which does not have such political power.

Critical practice in institutionalised organisations is promoted also due to a better funding system which is multi-source and not completely decentralised. If decentralisation and subsidiarity of funding took place and organisations operated at municipal level only, this could severely dampen the critical potential of social work, especially at local level. Due to some kind of detachment of regional or state funding from local social conflicts, it is still possible to compensate the financial retaliation of self-governments from more centralised sources. The higher the level of retaliation for activism, the more visible and politically risky it is. Paradoxically, greater centralisation of funding might be for the benefit of socially excluded people in specific local communities. Thus, the path to critical practice (among institutionalised organisations) seems to be social cap- 
ital and network increase (done by social workers in these organisations), merging into larger social holdings and promotion of funding centralisation.

In the case of non-institutionalised subjects, they should limit their isolated critical practice and join support networks that promote the interests of 'neoliberal offenders' together, including the participation of the poor themselves. The model may be the Social Work Action Network (SWAN) which has been dealing with the impact of economic policy on social work not only in the UK but also in Ireland, Greece and Spain. It brings together social workers, people in the academic area, students, and service users. All of these have common fears, and they are concerned about the fate of social work in the era of neoliberalism which is being devalued by social cuts, savings and underfunding, the removal of money from the public sphere and privatisation, the introduction of market mechanisms and competition, managerialism, and the weakening of solidarity.

\section{Contact}

Mgr. Radka Janebová, Ph.D.

University of Hradec Králové

Faculty of Arts, Institute of Social Work

Víta Nejedlého 573, 50000 Hradec Králové

radka.janebova@uhk.cz 